\title{
Microanatomical and Physicochemical
} Characterization and Antioxidative Activity of Methanolic Extract of Oudemansiella canarii (Jungh.) Höhn

\author{
Oudemansiella canarii (Jungh.) Höhn Metanollü Ekstresinin \\ Mikroanatomik ve Fizikokimyasal Karakterizasyonu ve Antioksidan \\ Aktivitesi
}

\author{
(D) Krishnendu ACHARYA*, (D) Sudeshna NANDI, (D) Arun Kumar DUTTA \\ University of Calcutta, Department of Botany, Kolkata, India
}

\begin{abstract}
Objectives: Oudemansiella canarii is an edible mushroom highly appreciated throughout the world due to its being a gastronomic delicacy. To date, no extensive work has been reported on the pharmacological or antioxidative aspects of this macrofungus. The present study focuses on the micromorphological features, confirmation of its identity based on molecular sequence (nrITS rDNA) data, and determination of its physicochemical parameters such as organoleptic features and fluorescent behavior.

Materials and Methods: Collected basidiocarps were powdered and used for microscopic and organoleptic evaluation. 2,2-Diphenyl-1-picrylhydrazyl (DPPH) radical scavenging method, total antioxidant activity methods, and 2,2-azinobis (3-ethylbenzothiazoline-6-sulfonic acid) (ABTS) assay were used for evaluating the antioxidant capacities of the methanolic extract. High-performance liquid chromatography (HPLC) analysis profile was also recorded to analyze the phenolic fingerprint.

Results: The DPPH radical scavenging activity was determined with an $\mathrm{EC}_{50}$ value of $0.912 \mu \mathrm{g}$, total antioxidant activity was found to be $15.33 \mu \mathrm{g}$ ascorbic acid equivalent/mg of extract, and the ABTS assay revealed $12.91 \mu \mathrm{m} \mathrm{TE} / \mathrm{mg}$ of extract antioxidant activity. The HPLC chromatogram revealed the presence of 12 peaks. Several parameters were tested for the determination of chemical composition, revealing the existence of major bioactive components in the extract in the following order: phenol>flavonoid $>$ ascorbic acid $>\beta$-carotene lycopene.

Conclusion: The present work suggests that $O$. canarii may be considered a novel prospect as a functional food and antioxidant supplement. Key words: Chromatographic fingerprinting, edible mushroom, fluorescence analysis, internal transcribed spacer, phytochemicals, West Bengal
\end{abstract}

ÖZ

Amaç: Oudemansiella canarii, gastronomik lezzeti nedeniyle dünya çapında değerli, yenilebilir bir mantardır. Bugüne kadar, bu makrofungusun farmakolojik veya antioksidan özellikleri hakkında kapsamlı bir çalışma bildirilmemiştir. Bu çalışmada, mikro-morfolojik özellikler, moleküler dizi (nrITS rDNA) verisine dayanarak kimliğinin doğrulanması, organoleptik özellikler ve floresan davranışı gibi fizikokimyasal parametrelerinin belirlenmesi amaçlanmıştır.

Gereç ve Yöntemler: Toplanan basidiokarplar toz haline getirilmiş ve mikroskobik ve organoleptik değerlendirme için kullanılmıştır. Metanollü ekstrenin antioksidan kapasitelerini değerlendirmek için 2,2-difenil-1-picrylhydrazyl (DPPH) radikal süpürme yöntemi, toplam antioksidan aktivite yöntemleri ve 2,2-azinobis (3-etilbenzotiyazolin-6-sülfonik asit) (ABTS) analizi kullanılmıştır. Fenolik parmakizi analizi için yüksek performanslı sıvı kromatografisi (HPLC) profili alınmıştır.

Bulgular: DPPH radikal süpürücü etki tayininde $\mathrm{EC}_{50}$ değeri $0.912 \mu$ g olarak belirlenmiş, toplam antioksidan aktivitenin $15.33 \mu g$ askorbik asit eșdeğeri/ mg ekstre olduğu bulunmuş ve ABTS analizinde $12.91 \mu \mathrm{m}$ TE/mg ekstre ile antioksidan aktivite gösterdiği belirlenmiștir. HPLC kromatogramı 12 pikin

*Correspondence: E-mail: krish_paper@yahoo.com, Phone: +91 8013167310 ORCID-ID: orcid.org/0000-0003-1193-1823

Received: 06.09.2017, Accepted: 28.12.2017

๑Turk J Pharm Sci, Published by Galenos Publishing House. 
varlığını ortaya çıkarmıştır. Ekstrenin kimyasal bileşiminin belirlenmesi ve majör biyoaktif bileşenlerin (sırasıyla; fenol>flavonoit>askorbik asit> $\beta$ karoten likopen) varlığının ortaya konulması için çeșitli parametreler incelenmiştir.

Sonuç: Bu çalışma, O. canarii'nin fonksiyonel bir gıda ve antioksidan takviyesi olarak yeni bir olasılık olarak kabul edilebileceğini göstermektedir. Anahtar kelimeler: Kromatografik parmakizi, yenilebilen mantar, floresans analizi, dahili kopyalanan aralayıcı, fitokimyasal, West Bengal

\section{INTRODUCTION}

For millennia mushrooms have had a prolonged connection with humankind and have had profound biological and economic impact. A recent assessment implied the existence of around 140,000 species, of which only $10 \%$ have been identified. Recently, scientists have reported that there are at least 7000 unrevealed macrofungi in the world that may have beneficial effects for mankind. Thus, there is a recent trend among mycologists to document edible mushrooms all around the globe.

West Bengal $\left(21^{\circ} 38^{\prime}-27^{\circ} 10^{\prime} \mathrm{N}\right.$ latitude and $85^{\circ} 50^{\prime}-89^{\circ} 50^{\prime} \mathrm{E}$ longitude) possesses unique phytogeographical features with variable altitudinal, climatic, and edaphic amalgamations. It is the only state in India that topographically extends from the Himalayas in the north to the Bay of Bengal in the south, with regions such as a plateau and the Ganges delta prevailing in between. These outspread ranges of topographical features and classes of soils and substrata make the state an ideal place for hosting a rich diversity of mushrooms. ${ }^{2}$ In previous years, our research team conducted extensive field works and recorded an immense number of wild edible mushrooms from different corners of the state with the help of tribal and ethnic forest dwellers of the regions who consume them as part of their daily diet. $^{3}$ Taxonomic and molecular exploration revealed that many of them are new to science, 4,5 new records for India, 6,7 and additions to the macrofungal flora of West Bengal. 8,9

Throughout the globe, mushrooms are well known to human civilizations because of having nutritional and culinary value and medicinal potential. In contemporary terms, they can be regarded as functional foods that can furnish health benefits beyond the traditional nutrients. ${ }^{10}$ Mushrooms are known to be rich sources of various bioactive substances like antioxidant, ${ }^{11-13}$ antimicrobial, ${ }^{14,15}$ immunomodulatory, ${ }^{16,17}$ and anticancer ${ }^{18}$ substances. Despite all the mentioned health promoting effects, this diverse group is still largely unknown as more than half of the species remain undescribed.

Most of the species belonging to the genus Oudemansiella (Basidiomycota, Agaricales, Physalacriaceae) are consumed worldwide. ${ }^{19}$ Many Oudemansiella species are known to contain bioactive compounds, such as oudenone and lectin (obtained from Oudemansiella radicata), ${ }^{20,21}$ and mucidin and oudemansin (from Oudemansiella mucida). ${ }^{22,23}$ The edible mushroom Oudemansiella canarii (Jungh.) Höhn was found to be present in various biomasses, where it colonizes with several plant species. Morphologically, the taxon is characterized by the presence of a medium to considerably larger pileus with glutinous to viscid surface colored gray-orange to orange white or with paler to white margin; adnate to shallowly adnexed, white, distant lamellae with 2-3 series of lamellulae; globose to subglobose basidiospores measuring $19-25 \times 18-23 \mu \mathrm{m}$ in diameter; an ixotrichoderm type of pileipellis; well-developed, stalked, pleuro- and cheilocystidia; presence of one- to few-celled caulocystidia with heterogeneous contents; and lignicolous habit. ${ }^{24}$ As it is considered an edible mushroom with good potential as a food source, it is highly cultivated artificially on various lignocellulosic substrates. ${ }^{25}$ Very few literature reports were found related to their physicochemical, nutritional, and medicinal value. Only one report has been published regarding the antifungal and biological activities of O. canarii. ${ }^{26}$ Therefore, in the present study we documented molecular parameters with the phylogeny, physicochemical profile, and antioxidant potentiality of $O$. canarii.

\section{MATERIALS AND METHODS}

\section{Sample collection and microscopic and organoleptic characterization of powdered basidiocarps}

Living basidiocarps of $O$. canarii were collected from the Gangetic plains of West Bengal, India. The basidiocarps were found to grow on dead and decayed woods of dicotyledonous plants. Identification of the specimen was done based on the standard literature. ${ }^{24,27}$ Collected basidiocarps were then dried overnight at $40^{\circ} \mathrm{C}$ using a field drier. A sample of the voucher specimen was deposited in Calcutta University Herbarium (CUH) following the protocol described by Pradhan et al. ${ }^{28}$ with the accession number CUH AM26. The remaining basidiocarps were used to make powder and then the powdered sample was hydrated and macerated with $10 \%$ potassium hydroxide $(\mathrm{KOH})$ and mounted on a glass slide for microscopic observations. For effective results, various stains (lactophenol and cotton blue, Melzer's reagent, congo red, etc.) were used to visualize different cellular structures such as hyphae, basidia, and spores. The slides were then viewed under a Leica DMLS microscope and images were captured at the desired magnification. Different organoleptic characters (i.e., color, odor, taste, and nature) of the powdered sample were evaluated.

\section{DNA extraction and polymerase chain reaction and cycle sequencing}

Genomic DNA was extracted and the desired region (nrDNA ITS) was amplified using the method described by Dutta et al. ${ }^{29}$ with the help of the primer pair ITS1 (forward) and ITS4 (reverse). ${ }^{30}$

\section{Fluorescence analysis}

Fluorescence analysis was performed as per the standard protocol. ${ }^{31}$ A small amount of sieved powder was kept on a clean grease-free microscopic slide and treated with prepared chemical agents including Hager's, Mayer's, Dragendroff's, phloroglucinol, and Barfoed's reagent and were mixed by gently tilting the slide. Then the slide was placed within a ultraviolet (UV) viewer chamber and viewed against visible, long (365 nm), and short 
(254 nm) UV radiations. Then the changes in color on application of these reagents in different radiations were recorded.

\section{Preparation of methanol extract}

Initial extraction was done using $100 \mathrm{~mL}$ of methanol overnight from the dried powdered fruit bodies $(5 \mathrm{~g})$ and then the solution was filtered using Whatman no. 1 filter paper. The residue was then re-extracted using $30 \mathrm{~mL}$ of methanol. Volume reduction of the combined methanolic extracts was done by evaporating at $40^{\circ} \mathrm{C}$ using a Buchi Rotavapor R3 (Switzerland). The methanolic fraction was then kept at $-20^{\circ} \mathrm{C}$ in a dark bottle until analysis, for not more than 1 month. Percentage yield and organoleptic features of the extract were recorded.

\section{Quantitative estimation of some important bioactive compounds}

Freshly prepared methanolic extract was subjected to several quantitative biochemical assays to investigate the presence and amounts of different phytochemicals. Folin-Ciocalteu reagent was used to estimate the content of total phenolic compounds in the extract ${ }^{32}$ with gallic acid as a standard. The results were expressed comparing with $\mu \mathrm{g}$ of gallic acid equivalents/mg of dry extract. Potassium acetate and aluminum nitrate were used to detect the presence of total flavonoid content. ${ }^{33} \mathrm{~A}$ standard curve was prepared with the help of quercetin $(5-20 \mu \mathrm{g} / \mathrm{mL})$. The results were expressed as $\mu \mathrm{g}$ of quercetin equivalents per $\mathrm{mg}$ of dry extract. $\beta$-Carotene and lycopene contents were estimated by measuring absorbance at 453, 505, and 663 $\mathrm{nm}$ wavelengths following the standard protocol. ${ }^{34}$ Ascorbic acid was determined by titration against 2,6-dichlorophenol indophenol dye..$^{35}$

High performance liquid chromatographic profile of methanol soluble extract

High performance liquid chromatographic (HPLC) analysis was performed to produce a fingerprinting profile of the extract. A $0.2 \mu \mathrm{m}$ filter was used to filter the methanolic extract and then $20 \mu \mathrm{L}$ of the filtrate was loaded in the HPLC system (Agilent, USA). Separation was performed on an Agilent Eclipse Plus C18 column $(100 \mathrm{~mm} \times 4.6 \mathrm{~mm}, 3.5 \mu \mathrm{m})$ with a flow rate of $0.8 \mathrm{~mL} / \mathrm{min}$ at $25^{\circ} \mathrm{C}$. The mobile phase comprised eluent $\mathrm{A}$ (acetonitrile) and eluent B (aqueous phosphoric acid solution, $0.1 \% \mathrm{v} / \mathrm{v}$ ). Further a gradient program was utilized for elution: 0-2 min, 5\% A; 2-5 min, 15\% A; 5-10 min, 40\% A; 10-15 min, $60 \% \mathrm{~A} ; 15-18 \mathrm{~min}, 90 \% \mathrm{~A}$. Finally, at $280 \mathrm{~nm}$, absorbance of the sample solution was measured. ${ }^{36}$

\section{Antioxidant activity}

For evaluation of the antioxidant potential of $O$. canarii, the methanolic extract was tested for several in vitro antioxidant activities by 2,2-diphenyl-1-picrylhydrazyl (DPPH) radical scavenging assay, 2,2'-azinobis-(3-ethyl-benzothiazoline-6 sulfonic acid (ABTS) assay, and total antioxidant assay.

\section{$D P P H$ radical scavenging activity}

The radical scavenging activity of the extract was tested using DPPH radicals following Mitra et al. ${ }^{37}$ Two milliliters of the reaction mixture contained several concentrations of the extract along with $0.1 \mathrm{mM}$ methanolic solution of DPPH. After $30 \mathrm{~min}$ of incubation at room temperature in the dark, the absorbance was measured against a methanol blank at $517 \mathrm{~nm}$. The $\mathrm{EC}_{50}$ value denotes an effective concentration at which $50 \%$ of the DPPH radicals are scavenged. Ascorbic acid was used for comparison. The scavenging ability was calculated using the following equation:

Scavenging effect $(\%)=\left\{\left(A_{0}-A_{1}\right) / A_{0}\right\} \times 100$

$A_{0}$ was absorbance of the control and $A_{1}$ was absorbance in the presence of sample. The percentage of inhibition was plotted against respective concentrations used.

\section{Total antioxidant activity}

Measurement of total antioxidant activity was solely based on the reduction of molybdenum (from $\mathrm{VI}$ to $\mathrm{V}$ ) by the sample analyte and thereby formation of phosphate/molybdenum (V) complex at acidic $\mathrm{pH}^{38}$ The sample was mixed with reagent solution, prepared with $28 \mathrm{mM}$ sodium phosphate, $0.6 \mathrm{M}$ sulfuric acid, and $4 \mathrm{mM}$ ammonium molybdate, and incubated at $95^{\circ} \mathrm{C}$ for $90 \mathrm{~min}$. The mixture was then cooled to room temperature. Absorbance was spectrophotometrically recorded for each solution at $695 \mathrm{~nm}$ using a blank sample as control. For reference antioxidant, various concentrations $(1-30 \mu \mathrm{g} / \mathrm{mL})$ of ascorbic acid were used and the total antioxidant capacity was expressed equivalent to ascorbic acid.

\section{ABTS radical scavenging activity}

ABTS is well regarded as a peroxidase substrate that generates a metastable radical cation when oxidized. ${ }^{39}$ The ability to inhibit the accumulation of ABTS radical cation by methanol extract and antioxidant standard, Trolox, was measured spectrophotometrically. ABTS dissolved in methanol to yield $7.4 \mathrm{mM}$ concentration. ABTS radical solution was prepared by reacting ABTS (7.4 mM) with $2.6 \mathrm{mM}$ potassium persulfate solution and permitting the mixture to stand in the dark for 12-16 $\mathrm{h}$ at room temperature before use. The mother stock was diluted to achieve an absorbance of $0.7 \pm 0.02$ at $734 \mathrm{~nm}$. Methanol extract at $1 \mathrm{mg} / \mathrm{mL}$ concentration was allowed to react with the ABTS working solution for $5 \mathrm{~min}$ and the absorbance was measured.

\section{Statistical analysis}

All the assays were performed in triplicate and the results are expressed by the mean values and standard deviation. For determining the significant difference among samples, the results were compared by means of Student's t-test. The analysis was carried out using Microsoft ${ }^{\circledR}$ Office Excel (Microsoft $^{\oplus}$, USA), where values of $p \leq 0.05$ were considered statistically significant.

\section{RESULTS AND DISCUSSION}

Microscopic and organoleptic characterization of the powdered basidiocarps

Dried powder of the fresh basidiocarps that was passed through sieve and further macerated with $\mathrm{KOH}$ showed basidiospores and fragmented hyphae (Figure 1). The hyphal system was 

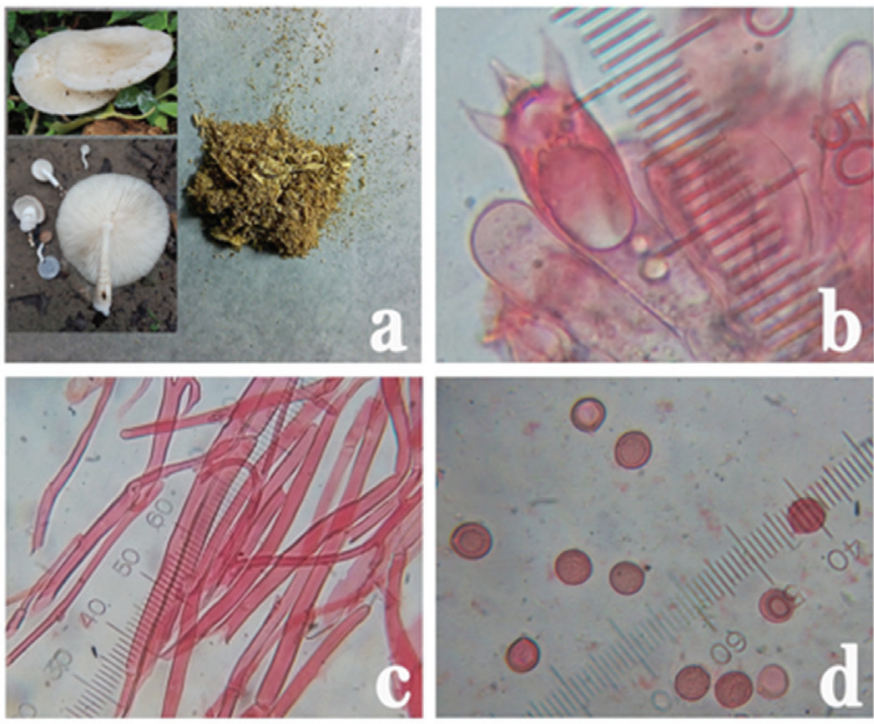

Figure 1. Macroscopic and microscopic characters of Oudemansiella canarii. a) sieved powder (fresh basidiocarps in insets), b) basidium, c) hyphae, d) basidiospores

monomitic in nature with generative hyphae that were 4-6 $\mu \mathrm{m}$ broad, septate, branched, hyaline, thin-walled, clamped. The basidia were $64-83 \times 11-22 \mu \mathrm{m}$ in diam., shaped clavate to broadly clavate and 4-spored at the apex. Basidiospores were 14-21×10.5-18 $\mu \mathrm{m}$ in diam., hyaline, globose to sub-globose with hilar appendage, and thick-walled. Melzer's reaction showed a negative result, which signifies the non-amyloid nature of the basidiospores.

Sieved powder was used for the organoleptic study. The powder was yellowish, with no odor, tasteless, and fibrous in texture.

\section{Molecular analysis}

The newly generated sequence of $O$. canarii was manually edited using the BioEdit sequence alignment editor v.7.0.9.0 (Ibis Biosciences, Carlsbad, CA, USA). The edited DNA sequence of the collected specimen produced 747-bp-long stretches that include the ITS1, 5.8S, ITS2, and 28S ribosomal RNA genes. The edited sequence was then used for the Basic Local Alignment Search Tool (BLAST) searches in the NCBI GenBank database (www.ncbi.nlm.nih.gov).

BLAST analyses with our newly generated sequence showed similarity with the genus Oudemansiella, with the highest similarity shown by 0 . canarii [AF321476, Identities $=681 / 698$ (98\%), Gaps=7/698 (1\%); KR265132, Identities=690/690 (100\%), Gaps $=0 / 690(0 \%)$. Hence, the result of the BLAST search easily helps to identify our collected specimen as $O$. canarii (family Physalacriaceae). The newly generated sequence of O. canarii was then deposited in the GenBank database with accession number KU647631.

\section{Fluorescence analysis}

The fluorescence test of the powdered sample was carried out for qualitative assessment of crude drug to give an idea of its chemical nature. The colors developed by these reagents represent the presence of active constituents. Analysis of powdered drug through fluorescence is a vital and very useful pharmacognostic technique for identification of authentic samples and recognizing adulterates and substituents to help in maintaining the quality, reproducibility, and efficacy of natural drugs. ${ }^{40,41}$ Here, powdered sample was treated with seven different chemical reagents and the characteristic fluorescence properties or colors were recorded (Table 1).

\begin{tabular}{|c|c|c|c|c|}
\hline \multirow{2}{*}{$\begin{array}{l}\text { Sl. } \\
\text { no. }\end{array}$} & \multirow[t]{2}{*}{ Reagent } & \multirow[t]{2}{*}{ Visible } & \multicolumn{2}{|l|}{ UV } \\
\hline & & & $\begin{array}{l}\text { Long } \\
(365 \mathrm{~nm})\end{array}$ & $\begin{array}{l}\text { Short } \\
(254 \mathrm{~nm})\end{array}$ \\
\hline 1 & Blank & Straw yellow & Brown & Straw yellow \\
\hline 2 & Water & $\begin{array}{l}\text { Cinnamon } \\
\text { brown }\end{array}$ & $\begin{array}{l}\text { Cinnamon } \\
\text { brown }\end{array}$ & Light brown \\
\hline 3 & Mayer's & $\begin{array}{l}\text { Grayish } \\
\text { orange }\end{array}$ & Dark brown & Pastel yellow \\
\hline 4 & Hager's & Cream & $\begin{array}{l}\text { Grayish } \\
\text { brown }\end{array}$ & $\begin{array}{l}\text { Grayish } \\
\text { orange }\end{array}$ \\
\hline 5 & Phloroglucinol & $\begin{array}{l}\text { Brownish } \\
\text { yellow }\end{array}$ & $\begin{array}{l}\text { Violet } \\
\text { brown }\end{array}$ & Dark brown \\
\hline 6 & $\begin{array}{l}\text { Barfoed's } \\
\text { reagent }\end{array}$ & Dark brown & $\begin{array}{l}\text { Grayish } \\
\text { brown }\end{array}$ & Violet brown \\
\hline 7 & $\begin{array}{l}\text { Dragendorff's } \\
\text { reagent }\end{array}$ & $\begin{array}{l}\text { Brownish } \\
\text { orange }\end{array}$ & Brown & Light brown \\
\hline
\end{tabular}

UV: Ultraviolet

\section{Quantitative estimation of bioactive compounds}

The quantitative estimation of several marked phytochemicals of the methanolic extract was carried out based on the standard protocols as described above. Phenolic compounds are well regarded as a powerful chain-breaking antioxidant because of the presence of hydroxyl groups with scavenging ability. It was found that the extract contained phenol as high as $5.38 \pm 0.55$ $\mu \mathrm{g}$ gallic acid equivalent/mg of extract. Total flavonoid content was estimated using quercetin as the standard. The flavonoid content was $1.875 \pm 0.78 \mu \mathrm{g}$ quercetin equivalent/mg of the extract while the ascorbic acid content was $1.10 \pm 0.42 \mu \mathrm{g} / \mathrm{mg}$. $\beta$-Carotene and lycopene were present in negligible amounts: $0.0342 \pm 0.004 \mu \mathrm{g} / \mathrm{mg}$ and $0.0238 \pm 0.004 \mu \mathrm{g} / \mathrm{mg}$ of the extract, respectively.

\section{Chromatographic fingerprinting by HPLC}

For preliminary determination of the presence of chemical constituents in any sample, one of the popular and efficient chromatographic methods is HPLC. Thus, HPLC analysis was carried out using the methanolic extract of $O$. canarii. The UV spectrum analysis of the chromatogram $(278 \mathrm{~nm}$ ) depicts the presence of 12 peaks excluding the mobile phase peak. The represented chromatogram may serve as a phenolic fingerprint for this mushroom. The HPLC chromatogram of methanolic extract of the sample identifies the presence of cinnamic acid (retention time $15.358 \mathrm{~min}$ ) and pyrogallol (retention time 15.966 


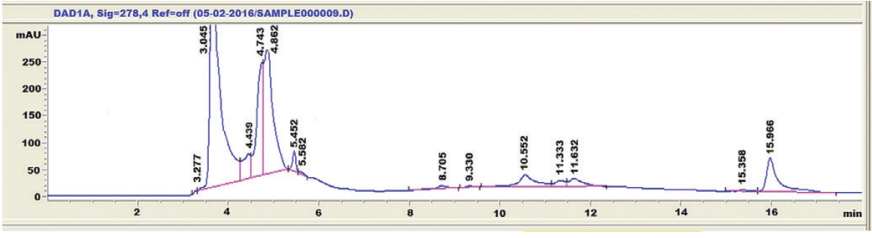

Figure 2. Enlarged HPLC chromatogram of methanol extract from Oudemansiella canarii

HPLC: High-performance liquid chromatography

Table 2. HPLC profile at $278 \mathrm{~nm}$ of methanol extract from Oudemansiella canarii

\begin{tabular}{llll} 
Peak no. & Retention time $(\mathrm{min})$ & Area (AU) & Maximum height (AU) \\
\hline 1 & 4.439 & 593.86871 & 46.60723 \\
\hline 2 & 4.743 & 2061.23242 & 211.45323 \\
\hline 3 & 4.862 & 3274.20972 & 239.57074 \\
\hline 4 & 5.452 & 198.42529 & 38.72375 \\
\hline 5 & 5.582 & 36.55459 & 4.50278 \\
\hline 6 & 8.705 & 85.07185 & 5.29850 \\
\hline 7 & 9.330 & 26.53930 & 2.48095 \\
\hline 8 & 10.552 & 623.75525 & 22.86010 \\
\hline 9 & 11.333 & 187.39143 & 11.74532 \\
\hline 10 & 11.632 & 341.26938 & 15.61782 \\
\hline 11 & 15.358 & 67.66934 & 4.10833 \\
\hline 12 & 15.966 & 1172.96606 & 63.93803 \\
\hline
\end{tabular}

min) based on the standard as provided in our previous study. ${ }^{15}$ The chromatographic profile along with the retention time of each peak is presented in Figure 2 and respective areas of each peak are documented in Table 2.

\section{Antioxidant activity}

\section{$D P P H$ radical scavenging activity}

The DPPH assay has been popularly used for testing the free radical scavenging ability of various natural samples. DPPH receives electrons or hydrogen to gain stability. Antioxidants, on the other hand could donate electrons or hydrogen atoms. In methanol solution, DPPH produces a violet color. However, when electrons are donated to DPPH, the solution starts losing color from purple to yellow and the reduction capacity of DPPH is determined by the decrease in its absorbance at $517 \mathrm{~nm} .{ }^{42}$ The extract showed high effective free radical scavenging activity in the DPPH assay at the rate of $6.53 \%, 55.85 \%$, and $78.74 \%$ at 0.5 , 1 , and $1.5 \mathrm{mg} / \mathrm{mL}$ concentrations (Figure 3 ). The $\mathrm{EC}_{50}$ value was $0.912 \pm 0.38 \mathrm{mg} / \mathrm{mL}$.

\section{Total antioxidant activity}

One of the simplest methods for evaluating total antioxidant capacity is the phosphomolybdenum method. The total antioxidant capacity of the methanol fraction was investigated and compared against ascorbic acid. The extract revealed antioxidant capacity of $15.33 \pm 0.67 \mu \mathrm{g} / \mathrm{mg}$ ascorbic acid equivalent.

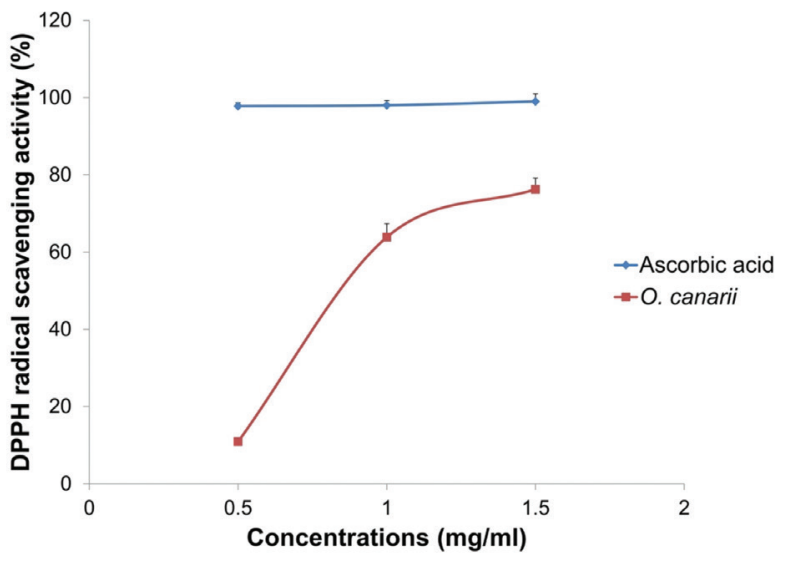

Figure 3. DPPH assay of methanol extract from dried basidiocarp of Oudemansiella canarii

DPPH: 2,2-Diphenyl-1-picrylhydrazyl

\section{ABTS radical scavenging activity}

The ABTS assay is based on the inhibition of the formation of ABTS+, a stable radical cation by one electron oxidants. The methanolic extract of the sample showed $12.91 \pm 0.26 \mu \mathrm{M}$ Trolox equivalents/mg of extract antioxidant activity.

\section{CONCLUSIONS}

The present work allocates standards of the macrofungus 0 . canarii with the help of pharmacognostic, molecular, and chemical characteristics. Various standardization parameters such as microscopy, molecular characteristics, physicochemical constants, preliminary mycochemical quantification, HPLC analysis, and antioxidant activity were studied, and were reported for the first time for this mushroom. All these combined data indicate this edible mushroom is a valuable source of bioactive molecules like phenolic compounds and has enormous antioxidant potential.

Conflict of Interest: No conflict of interest was declared by the authors.

\section{REFERENCES}

1. Thatoi H, Singdevsachan SK. Diversity, nutritional composition and medicinal potential of Indian mushrooms: a review. Afr J Biotechnol. 2014;13:523-545.

2. Dutta AK, Acharya K. Traditional and ethno-medicinal knowledge of mushrooms in West Bengal, India. Asian J Pharm Clin Res. 2014;7:36-41.

3. Dutta AK, Pradhan P, Basu SK, Acharya K. Macrofungal diversity and ecology of the mangrove ecosystem in the Indian part of Sundarbans. Biodiversity. 2013;14:196-206.

4. Acharya K, Dutta AK, Pradhan P. A new variety of Volvariella pusilla from West Bengal, India. Mycosphere. 2012;3:13-17.

5. Dutta AK, Chandra S, Pradhan P, Acharya K. A new species of Marasmius sect. Sicci from India Mycotaxon. 2014;128:117-125.

6. Dutta AK, Pradhan P, Roy A, Acharya K. A subtropical agaric new to India. Kavaka. 2011;39:37-39. 
7. Dutta AK, Pradhan P, Roy A, Acharya K. Agaricales of West Bengal, India. I. Clavariaceae: Clavaria and Scytinopogon. Ind JAppl Pure Biol. 2012;27:53-58.

8. Dutta AK, Chakraborty N, Pradhan P, Acharya K. Phallales of West Bengal, India. II. Phallaceae: Phallus and Mutinus. Researcher. 2012;4:21-25.

9. Acharya K, Pradhan P, Sherpa NL, Dutta AK. Favolaschia a new fungal genus record for Eastern India. Ind For. 2014;140:639-640.

10. Rathee S, Rathee D, Rathee D, Kumar V, Rathee P. Mushrooms as therapeutic agents. Rev Bras Farmacogn. 2012;22:459-474.

11. Khatua S, Mitra P, Chandra S, Acharya K. In vitro protective ability of Ramaria aurea against free radical AND indentification of mail phenolic acids by HPLC. J Herbs Spices Med Plants. 2015;21:380-391.

12. Pattanayak M, Samanta S, Maity P, Sen IK, Nandi AK, Manna DK, Mitra P, Acharya K, Islam SS. Heteroglycan of an edible mushroom Termitomyces clypeatus: structure elucidation and antioxidant properties. Carbohydr Res. 2015;413:30-36.

13. Dasgupta A, Paloi S, Acharya K. Mycochemical analysis and antioxidant efficacy of a wild edible mushroom from the Eastern Himalayas. Res J Pharm Biol Chem Sci. 2015;6:943-948.

14. Mallick S, Dey S, Mandal S, Dutta A, Mukherjee D, Biswas G, Chatterjee S, Mallick S, Lai TK, Acharya K, Pal C. A novel triterpene from Astraeus hygrometricus induces reactive oxygen species leading to death in Leishmania donovani. Future Microbiol. 2015;10:763-789.

15. Khatua S, Dutta AK, Acharya, K. Prospecting Russula senecis: a delicacy among the tribes of West Bengal. Peer J. 2015;3:810.

16. Maity P, IK S, Majia PK, Paloi S, Devi KS, Acharya K, Maiti TK, Islam SS. Structural, immunological, and antioxidant studies of $\beta$-glucan from edible mushroom Entoloma lividoalbum. Carbohydr Polym. 2015;123:350-358.

17. Samanta S, Nandi AK, Sen IK, Maity P, Pattanayak M, Devi KS, Khatua S, Maiti TK, Acharya K, Islam SS. Studies on antioxidative and immunostimulating fucogalactan of the edible mushroom Macrolepiota dolichaula. Carbohydr Res. 2015;413:22-29.

18. Chatterjee S, Biswas G, Chandra S, Saha GK, Acharya K. Chemopreventive effect of Tricholoma giganteum against benzo[a]pyrene-induced forestomach cancer in Swiss albino mice. Int J Pharm Sci Rev Res. 2014:26:189-196.

19. Xu F, Li Z, Liu Y, Rong C, Wang S. Evaluation of edible mushroom Oudemansiella canarii cultivation on different lignocellulosic substrates. Saudi J Biol Sci. 2016;23:607-613.

20. Tsantrizos YS, Yang X, McClory A. Studies on the Biosynthesis of the Fungal Metabolite Oudenone. 2. Synthesis and Enzymatic Cyclization of an alpha-Diketone, Open-Chain Precursor into Oudenone in Cultures of Oudemansiella radicata. J Org Chem. 1999;64:6609-6614.

21. Liu $Q, N g T$, Wang $H$. Isolation and characterization of a novel lectin from the wild mushroom Oudemansiella radicata (Relhan.: Fr.) Sing. Biotechnol Bioprocess Eng. 2013;18:465-471.

22. Subik J, Behun M, Smigan P, Musilek V. Mode of action of mucidin, a new antifungal antibiotic produced by the basidiomycete Oudemansiella mucida. Biochim Biophys Acta. 1974;343:363-370.

23. Anke T, Hechi HJ, Schramm G, Steglich W. Antibiotics from Basidomycetes. IX. Oudemansin, an antifungal antibiotic from Oudemansiella mucida (Schrader ex Fr.) Hochnel (Agaricales). J Antibiot (Tokyo) 1979;32:1112-1117.

24. Petersen RH, Desjardin DE, Krüger D. Three type specimens designated in Oudemansiella. Fungal Divers. 2008;32:81-96.
25. Silveira RMJ, Tauk TSM, Bonomi VLR, Capelari M. Cultivation of the edible mushroom Oudemansiella canarii (Jungh.) Hönn. In Lignocellulosic substrates. Braz J Microbiol. 2001;32:211-214.

26. Rosa LH, Cota BB, Machado KMG, Rosa CA, Zani CL. Antifungal and other biological activities from Oudemansiella canarii (Basidiomycota). World $J$ Microbiol Biotechnol. 2005;21:983-987.

27. Corner EJH. On the Agaric genera Hohenbuehelia and Oudemansiella. Part II: Oudemansiella, Gard Bull Singapore, 1994:49-75.

28. Pradhan P, Dutta AK, Acharya K. A low cost long term preservation of macromycetes for fungarium. Protocol Exchange; 2015.

29. Dutta AK, Wilson AW, Antonin V, Acharya K. Taxonomic and phylogenetic study on gymnopoid fungi from Eastern India. I. Mycol Progress. 2015;14:79.

30. White TJ, Bruns T, Lee S, Taylor J. PCR Protocols: a Guide to Methods and Applications. In: Innis MA, Gelfand DH, Sninsky DH, White TJ, eds. Amplification and direct sequencing of fungal ribosomal RNA genes for phylogenetics. Orlando; Florida; 1990:315-322.

31. Kokashi CJ, Kokashi RJ, Sharma M. Fluorescence was powdered vegetable drugs under ultraviolet radiation. J Am Pharm Assoc Am Pharm Assoc. 1958;47:715-717.

32. Singleton VL, Rossi JA. Colorimetry of total phenolics with phosphomolybdic- phosphotungstic acid reagents. Am J Enol Viticult. 1965;16:44-158.

33. Adebayo EA, Oloke JK, Ayandele AA, Adegunlola CO. Phytochemical, antioxidant and antimicrobial assay of mushroom metabolite from Pleurotus pulmonarius -LAU 09 (JF736658). J Microbiol Biotech Res. 2012;2:366-374.

34. Nagata M, Yamashita I. Simple method for simultaneous determination of chlorophyll and carotenoids in tomatoes fruit. J Jpn Soc Food Sci. 1992;39:925-928.

35. Rekha C, Poornima G, Manasa AV, Pavithra DJ, Vijay KHT, Prashith KTR. Ascorbic acid, total phenol content and antioxidant activity of fresh juices of four ripe and unripe citrus fruits. Chem Sci Trans. 2012;1:303-310.

36. Mitra P, Mandal N, Acharya K. Biocomponents and bioprospects of ethanolic extract of Termitomyces heimii. Asian J Pharm Clin Res. 2015;8:331-334.

37. Mitra P, Mandal NC, Acharya K. Phytochemical characteristics and free radical scavenging activity of ethanolic extract of Termitomyces microcarpus R. Heim. Der Pharmacia Lettre. 2014:6:92-98.

38. Prieto P, Pineda M, Aguilar M. Spectrophotometric quantitation of antioxidant capacity through the formation of phosphomolybdenum complex: specific application to the determination of vitamin E. Anal. Biochem. 1999;269:334-337.

39. Arnao MB, Cano A, Hernandez-Ruiz J, Garcia-Canovas F, Acosta M. Inhibition by L-ascorbic acid and other antioxidants of the $2.2^{\prime}$-azinobis (3-ethylbenzthiazoline-6-sulfonic acid) oxidation catalyzed by peroxidase: a new approach for determining total antioxidant status of foods. Anal Biochem. 1996;236:255-261.

40. Bhattacharya S, Zaman MK. Pharmacognostical evaluation of Zanthoxylum nitidum bark. Int J Pharm Tech Res. 2009;1:292-298.

41. Sonibare MA, Olatubosun OV. Pharmacognostic and free radical scavenging evaluation of Cyathula prostata (Blume) L. Phcog J. 2015;7:107-116.

42. Shimada K, Fujikawa K, Yahara K, Nakamura T. Antioxidative properties of Xanthan on the autoxidation of soybean oil in cyclodextrin emulsion. $J$ Agric Food Chem. 1992;40:945-948. 